\title{
Identidade Constitucional no Estado Federal: uma Concepção \\ Legitimadora
}

\author{
Vencedor do X Concurso Brasiliense de Monografias Jurídicas
}

\author{
GABRIEL FORTES \\ Advogado, Bacharel em Direito pela Universidade de Fortaleza, Pós-Graduando em Direito Pro- \\ cessual pela Faculdade Sete de Setembro, Técnico em Contabilidade pelo IASOCIAL, Membro \\ da Comissão de Políticas Urbanas e Direito Urbanístico da OAB/CE.
}

RESUMO: De acordo com o que foi explicitado ao longo deste trabalho, em resumo, o que faz uma Constituição ser boa e duradoura, acima de tudo, é o fato de que ela possa, enquanto normatização institucional da convivência social, refletir, ao máximo possível, a vontade do povo, isto é, que se formule como reflexo dos valores e da cultura política, voltada para atuar conforme a realidade do ambiente social em que se inscreve. A Constituição, nesse sentido, deve funcionar como marco normativo substancialmente legítimo; nela o povo deve identificar-se enquanto comunidade política. Para isso, inegavelmente, a ordem constitucional deve ser construída de maneira democrática, com a efetiva participação popular, não apenas na sua etapa de confecção, mas inclusive durante os momentos decisivos de sua concretização, em um processo deliberativo pluralista que permita a inclusão política e a cooperação solidária. Mas os ambientes em que estão circunscritos os atores sociais dessa cidadania ativa certamente não são os grandes fóruns "nacionais" dos macrodebates teóricos, senão os espaços geopolíticos: locais onde a Constituição ganha vida e deve ser efetivada; onde ela é substancialmente materializada. E, com o destaque do localismo, outros preceitos estruturais como descentralização, autonomia, diversidade e tolerância anunciam as condições favoráveis de um sistema pluralista, que encontra na estrutura político-institucional do federalismo a ressonância necessária para concretização de uma democracia constitucional. E isso ocorre não apenas porque a descentralização política do sistema federativo permite maior aproximação entre governantes e governados, favorecendo um espaço onde ambos atuem como atores responsáveis e responsabilizáveis, mas também porque permite a reaproximação entre a sociedade civil e o Estado, em um contexto de crise global dos vínculos abstratos e das identidades homogeneizadas pelo constitucionalismo do Estado-nação. A atuação dos grupos sociais, nesse sentido, é a primeira que emerge como forma de buscar restabelecer os vínculos de cidadania e solidariedade enfraquecidos pela globalização, observando-se que os ambientes locais constituem espaço político natural para o resgate da legitimidade da atuação no espaço público. É nas bases do localismo, portanto, que a cidadania, a política e a Constituição ganham vida. Ademais, a autonomia federativa permite que as comunidades políticas locais formulem ordens constitucionais próprias, complementares à Constituição nacional, porém voltadas para atender à diversidade - cultural, étnica, linguística etc. - das realidades verificadas das sociedades pluralistas contemporâneas, o que se mostra como um sistema que favorece a legitimação e a conformação de uma identidade constitucional, construída a partir da atuação popular, cujos cidadãos se sujeitam a um ordenamento de cuja criação participam, refletindo seus valores e suas realidades, consolidando-se o respeito à normatividade e à estabili- 
dade constitucional. Em suma, o que faz uma Constituição ser boa e duradoura é o fato de que ela, sendo construída e concretizada democraticamente, mantendo vivo o princípio do pluralismo, reflita, como um espelho, os laços societários que unem a comunidade política debaixo de uma norma que identifique seus valores e sua autocompreensão política - uma apreensão que é naturalmente consumada na autonomia do Estado federal.

PALAVRAS-CHAVE: Democracia; participação popular; pluralismo político; federalismo; identidade constitucional.

ABSTRACT: What takes a Constitution to be good and lasting, above all, is its capability of, while a institutionalized rule for social partnership, reflecting, as much as possible, the will of the people, or so, being formulated as a reflection of the values and political culture, to rule among the reality of the social environment in which it is included. The Constitution, in this sense, should function as a substantially legitimate legal framework, in which people must identify themselves as a political community. For this a democratic performance must take place in order to build and also to apply and to achieve the rules of the constitutional order, through a pluralistic deliberative process that allows the political inclusion and cooperation. However the ambience where those social actors that active citizenship are circumscribed are certainly not the major "national" forums of theoretical macro-debates, but the local geopolitical areas where the Constitution pulses to become effective, where it is substantially materialized. In this sense, localism becomes a highlighted political aspect, which among some other structural precepts, such as decentralization, autonomy, diversity and tolerance, announce the favorable conditions for a pluralistic system that founds in the federalism the political and institutional structure to resonance the needed conditions to implement a constitutional democracy. And this is not only because the political decentralization of the federative system allows greater proximity between the "rulers and the ruled", opening space to a political controlled interaction, but also because it allows the rapprochement between the State and civil society in a context of global crisis that has been affecting the abstract linkages and identities homogenized by the "nationalistic constitutionalism". The role played for social groups, in this sense, emerges as a way of seeking to restore the bonds of citizenship and public solidarity, which have been weakened by globalization, and the local ambiences, thus, are naturally the political space where the public movement's legitimacy would be rescued. It is in the basis of localism, then, where citizenship, politic and the Constitution come alive. Moreover, the federal autonomy of local communities to formulate their own constitutional orders, complementing the national Constitution, but geared to protect the - cultural, ethnic, linguistic etc. - diversity of the different social realities that characterize contemporary pluralistic societies. And this aspect shows how a system that excels the legitimacy and rear the formation of a constitutional identity, built from the popular action, can be harbored by federalism, which provide citizens to become masters of the rule they must respect, for it reflects their values, consolidating the reverence to the constitutional stability. In few words, a Constitution might be good and lasting when it, being built and implemented democratically, keeping alive the main principle of pluralism, reflects, as a mirror, the social bonds that unite the political community under a standard that identifies the values and the political self-understanding process of the citizens; an aspect that is naturally accomplished in the autonomy provided by federalism to the local realms.

KEYWORDS: Democracy; popular participation; political pluralism; federalism; constitutional identity.

SUMÁRIO: Introdução; A democracia na contemporaneidade; Cidadania democrática: pluralismo e participação; Federalismo e identidade constitucional; Conclusão; Referências. 


\section{INTRODUÇÃO}

O século XX foi marcado por grandes mudanças na sistemática política do Mundo Ocidental, principalmente a partir da $2^{\text {a }}$ Guerra Mundial, quando a preocupação com as "marcas" deixadas pelo desgaste entre constitucionalismo e política passou a tomar conta dos debates filosóficos. Naquele contexto, a redemocratização dos Estados e a busca pela superação do totalitarismo homogeneizante foram pautadas por ideias de tolerância sociocultural, reconhecimento da diversidade e, destacadamente, redistribuição do poder, em uma proposta de inclusão social. O pluralismo, assim, destacou-se como ideia central das novas tendências do constitucionalismo. Mas essa nova configuração demandou, ademais, maior aproximação entre o povo e exercício do poder, no afã de conter a (re)centralização e (re)alienação do espaço político' ${ }^{1}$, de modo a descentralizar, democratizar e legitimar as decisões, refreando-se os desvios da representação política. E, assim, a postulação por uma democracia participativa ganhou maior destaque.

Todavia, é inegável que, principalmente nos países em desenvolvimento, essa perspectiva não tenha sido contemplada de maneira satisfatória, e, assim, os desvios do processo político vêm repercutindo diretamente na efetivação dos valores constitucionais-democráticos que deveriam norteá-lo, principalmente em razão da situação socioeconômica que envolve as comunidades nesses Estados, o que tem agravado a notória crise em que, há tempos, se encontra a cidadania emergente.

De outro lado, a superação da homogeneidade patrocinada pelo constitucionalismo tradicional vê na crise do nacionalismo a necessidade de busca por uma nova legitimação político-constitucional, que, nas sociedades fragmentadas contemporâneas, parte desde a (re)constituição de laços de solidariedade e autorreconhecimento, frente à atual ordem global que tem comprometido não apenas as identidades culturais, sociais etc., mas a própria identidade constitucional, que comumente não consegue estabilidade nem reflete os valores multifacetados do pluralismo insurgente.

Nesse sentido, então, buscou-se realizar, neste trabalho, uma análise conjugada e integrativa entre democracia, pluralismo e constitucionalismo, tendo por palco o arcabouço conceitual do Estado federal, em uma proposta de reconhecimento da autonomia política das localidades federativas como um espaço de legitimação e de (re)construção de um projeto republicano de cidadania, no qual a participação popular possa atuar na construção de um ordenamento constitucional que reflita e identifique os valores e os anseios reais e concretos da diversidade sociopolítica.

1 Como se deu desde os regimes totalitários da Europa e Ásia até as ditaduras militares da América Latina. 


\section{A DEMOCRACIA NA CONTEMPORANEIDADE}

Entre várias conceituações possíveis, Hans Kelsen (2000, p. 35) resume que democracia deve significar "identidade entre governantes e governados, entre sujeito e objeto do poder, governo do povo sobre o povo". Uma descrição nesses moldes, contudo, requer o mínimo de sistematização, de modo que se possam definir elementos e regras capazes de, política e juridicamente, assegurar e, ao mesmo tempo, evidenciar o governo do povo, pelo povo e para o povo.

Tal conceito, todavia, sendo genérico e, por certo, abstrato, é algo não apenas praticamente intangível, como incomensurável, visto que, se, por um lado, "não é possível estabelecer quantas regras devem ser observadas para que um regime possa dizer-se democrático" (BOBBIO, 2007, p. 327), é certo, por outro, que "nenhum Estado jamais possuiu um governo que estivesse plenamente de acordo com os critérios de um processo democrático" (DAHL, 2001, p. 53), no sentido mais puro do termo. Mas, até que se haja definido um significado comportamental de democracia, certamente não será um regime democrático aquele que não observar regras básicas desse processo, tradicionalmente definidas pela supremacia do órgão legislativo eleito, garantindo-se aos cidadãos o direito de votar, de maneira livre e isonômica, em diferentes partidos políticos, para que as eleições e decisões políticas sejam adotadas pelos critérios de maioria, sem, no entanto, limitarem-se os direitos das minorias, que devem poder competir em igualdade de condições, entre outras regras (BOBBIO et al, 2007, p. 327).

É possível reconhecer, a partir daí, que a apuração da existência de um regime democrático não pode, de fato, limitar-se a uma mera autodecretação formal de que uma dada sociedade constitui um Estado Democrático de Direito. Robert Dahl (2001, p. 99) sugere, reiterando o pensamento de Bobbio, um conjunto mínimo de instituições políticas capazes de caracterizar a presença de um sistema democrático: "1) funcionários [políticos] eleitos; 2) eleições livres, justas e frequentes; 3 ) liberdade de expressão; 4) fontes de informação diversificadas; 5) autonomia para as associações; 6) cidadania inclusiva", entre outras variações.

É necessário, pois, que os preceitos para um processo democrático estejam presentes no sistema institucional do Estado, enraizados na sua organização política, fazendo-o funcionar de acordo com essa perspectiva no âmbito econômico, social, jurídico, cultural etc. Portanto, é essencial, para a estabilidade democrática a institucionalização de um adequado sistema político (BAQUERO, 1988, p. 21).

Mas um sistema político institucional deve servir de instrumento para a finalidade democrática e, ao mesmo tempo, ser baseado nos valores e princípios que dão fundamento à opção pela democracia. É necessário, então, que seja delimitado, ainda que de maneira sucinta, o objeto e os sujeitos de um 
regime democrático, para que se possam identificar os meios adequados para sua concretização.

Conforme sintetiza José Afonso da Silva (2010, p. 126), "democracia é um processo de convivência social em que o poder emana do povo, há de ser exercido, direta ou indiretamente, pelo povo e em proveito do povo". Assim, se, desde suas raízes gregas históricas, a democracia designa o poder do povo, não poderá, enquanto processo, ser concebida de maneira engessada ou, de certa forma, dogmática, mas sim modelável e adaptável, antes empírica do que teoricamente, embora não se possam olvidar seus elementos principais de identificação (GOYARD-FABRE, 2003, p. 212).

Aristóteles (2010, p. 155), ao analisar as várias espécies aparentemente concebíveis de regimes democráticos, apontava a definição de um sistema no qual

[...] a lei diz que o pobre não tem mais direito que os ricos e que nenhum deles é o senhor, mas todos são iguais, pois, se liberdade e igualdade são consideradas [...] essenciais na democracia, então elas só podem existir em sua plenitude se todos os cidadãos usufruírem perfeita igualdade política.

Destaca Aristóteles, portanto, a lei como regra que permite a concretização da liberdade a partir de uma perspectiva de isonomia dos atores sociais. Por isso dizia que a salvaguarda da Cidade - local da vida política - estaria na igualdade dos cidadãos, desde que isso permitisse a alternância no poder, de modo que todos pudessem passar pelo governo (ARISTÓTELES, 2010, p. 7980). E, nesse sentido, o princípio da igualdade certamente pode ser visto como núcleo democrático da cidadania (NEVES, 2008, p. 175). Nesse diapasão, todavia, observa John Stuart Mill (1981, p. 71):

A ideia pura de democracia, de acordo com a sua definição, é o governo do povo inteiro pelo povo inteiro, representado de maneira igual. A democracia, da maneira como é comumente concebida e até agora praticada, é o governo do povo inteiro por uma mera maioria, exclusivamente representada. A primeira ideia é sinônimo da igualdade de todos os cidadãos; a segunda, estranhamento confundida com a primeira, é um governo de privilégios, em nome da maioria numérica, que é praticamente a única a ter voz no Estado.

Na percepção de Mill, a práxis democrática contemporânea, de fato, acaba ensejando certa "distorção" da ideia primária do regime democrático. E isso pode ser justificado - ou, ao menos, explicado - a partir da noção de que a institucionalização da democracia teve sempre dois significados prevalecentes, ao menos na origem, variando conforme o destaque que se pudesse dar ao conjunto de regras que permite a distribuição do poder político à maior parte dos cidadãos ou ao ideal de igualdade, no qual todo governo democrático dever-se-ia inspirar (BOBBIO, 2000, p. 38). 
Nesse sentido, portanto, a onipotência da democracia pode, com efeito, servir à contemplação de uma espécie de tirania da maioria, vergastadora dos direitos das minorias, mas legitimada pela lei (GOYARD-FABRE, 2003, p. 217) e, nessa perspectiva, pouco efeito prático causará a ideia de igualdade formal perante as normas da democracia, enquanto limitada à regra de "um cidadão, um voto".

Mas, em uma acepção mais ampla, igualdade também poderá significar que o demos assuma alguns compromissos para fazer com que cada um dos cidadãos possa participar de um núcleo comum de direitos básicos e condições de bem-estar (STEPAN, 1999, p. 4), uma vez que a igualdade inerente à cidadania somente poderia ser alcançada, caso se se estendesse, simultaneamente, "à liberdade (civil), à participação (política) e à satisfação das necessidades (sociais)" (NEVES, 2008, p. 176). Assim, isonomia civil, política e social seriam perspectivas indissociáveis em um sistema democrático.

Sabe-se, por certo, que a igualdade de voto não é condição suficiente - embora seja necessária - para a configuração de um processo democrático, o qual, além disto, demanda, para sua concretização, que outros predicados sejam conferidos aos cidadãos, servindo de critérios de aferição democrática, apontados por Robert Dahl (2001, p. 49-50) como: participação efetiva; entendimento esclarecido; controle do programa de planejamento público; inclusão dos adultos ${ }^{2}$. Mas tais requisitos certamente não serão suficientes para que tenha lugar o fenômeno democrático, uma vez que o primeiro ponto citado é comumente afetada por questões de ordem socioeconômica, como "desigualdade em recursos, diferenças em capacitação e diferenças em incentivos para o uso de recursos a fim de ganhar influência" (DAHL, 1988, p. 105).

E, nesse contexto, observa Friedrich Müller (2010, p. 114) que a desigualdade social é verdadeiro fator de risco para a democracia, pois "o descenso econômico leva rapidamente à privação sociocultural e à apatia política - o que, quase sempre, satisfaz aos desígnios das esferas dominantes da sociedade". E por isso não é equívoco vincularem-se as exigências da democracia às condições sociais, políticas e econômicas dos cidadãos (SANTOS, 2007, p. 85).

Diante disso, faz-se necessário ter-se em conta a evolução histórica que a democracia sofreu nos últimos anos, especialmente após os avanços dos processos socioeconômicos, nos últimos tempos.

De acordo com as explicitações de Boaventura de Sousa Santos (2007), ainda no século XX, vários modelos de democracia podiam ser identificados: a forma representativa liberal, a democracia popular, a democracia participativa, a democracia dos países que se desenvolviam a partir do colonialismo etc.

2 Aqui se refere o autor às pessoas com maioridade político-eleitoral. 
Mas a tensão criada pelo capitalismo, acentuando as desigualdades sociais ao mesmo tempo em que excluía do processo político as minorias econômicas, incitou como contrapeso a busca pela criação de condições jurídico-políticas para a participação - porquanto a democracia busca a inclusão no contrato social -, a partir do reconhecimento de direitos econômicos e sociais, como condições sine qua non para garantia da liberdade e da igualdade (SANTOS, 2007, p. 85-86).

A sociedade civil, com todas as suas mazelas econômicas, passou a ser vista como "problema", cuja solução se depositava na atuação do Estado; montava-se um Estado democraticamente forte para fazer uma sociedade civil igualmente forte, acarretando a socialização da economia e a politização do Estado (que, ao mesmo tempo em que promovia a inclusão, fomentava as ideias de identidade nacional, bem-estar social, segurança individual e coletiva e soberania nacional) (SANTOS, 2007, p. 86-87).

Mas, com a crise desse modelo, especialmente após o colapso do socialismo soviético e do movimento nacionalista ocidental, apenas o modelo de democracia representativa perdurou, no contexto de neoliberalismo mundial. Assim, diz Boaventura de Sousa Santos (2007, p. 87-88), desapareceu a tensão entre capitalismo e democracia, revelando-se, porém, a atual crise do contrato social, cujos efeitos mais imediatos estão relacionados à exclusão socioeconômica, à manutenção do modelo liberal-representativo e à ausência de redistribuição.

E, com a ascensão do neoliberalismo, o Estado, regulador e gestor socioeconômico, passou a ser visto como problema, cuja solução estaria na livre iniciativa da sociedade. Assim, de espelho, o Estado passou a ser o tido como oposto da sociedade civil, o que operou a desnacionalização da economia, impulsionada pelas pressões internacionais, e a desestatização da regulação social (SANTOS, 2007, p. 88-89). Ocorre, porém, que, nesse quadro, "a esfera pública (e também o público como dimensão interna do sistema político) torna-se 'anestesiada' de tal maneira que se viabiliza a prevalência de interesses particularistas em detrimento do pluralismo" (NEVES, 2008, p. 225).

Como consequência desse sistema encontram-se o descaso com os direitos sociais e políticos, que não veem sua efetivação concretizar-se, a prevalência do capital multinacional sobre os postulados constitucionais e, como resultado, o que Boaventura Santos chamou de "democracia de baixa intensidade", cujas características espelham a confusão entre os mercados econômico e político (em um contexto no qual somente passa a ter valor aquilo que tem preço), dando-se margem à prática da corrupção como mecanismo-chave para afastar os cidadãos da vida política, o que se instrumentaliza, por fim, com a manutenção de uma democracia liberal representativa (SANTOS, 2007, p. 90-91).

A crítica feita pelo autor ao regime político liberal decorre da constatação de que, não obstante a democracia representativa significar, por um lado, 
autorização e, por outro, prestação de contas, ultimamente permanece em vigor o primeiro (o sistema de autorização), mas não se vê ocorrer o segundo (a prestação de contas). E a crise desse modelo acarreta a falta de representatividade cidadã, o que gera, consequentemente, o abstencionismo político (SANTOS, 2007, p. 91-92).

Essa conjuntura coaduna-se à percepção de Marcelo Neves (2008, p. 224-225), no sentido de que, entre as complexas causas de obstância à sua efetivação, o Estado Democrático de Direito, além dos problemas inerentes à nova ordem global, confronta-se, internamente, "com o problema de uma crescente indiferença da população não apenas em relação aos conteúdos das decisões políticas e normas jurídicas, mas também com respeito ao significado de seus procedimentos básicos".

E é nessa estrutura sociopolítico-econômica - que se retroalimenta dos próprios vícios que produz - que se opõem os bloqueios mais fortes à concretização dos valores republicanos, não se deixando lugar para o "estímulo das virtudes cívicas", como "participação ativa da população nas decisões políticas", "respeito à res publica", "percepção do cidadão enquanto membro da coletividade" etc. (AGRA, 2005, p. 13-14).

Essa cidadania bloqueada acaba encontrando seu primeiro limite, assim, não antes na falta de participação na vida política do que na própria falta de condições de participação; ou melhor, identifica-se um sistema que permite ao cidadão participar, mas sem conseguir influir nas regras de participação. E por isso urge a necessidade de "reinventar a diversidade da democracia", sendo que uma das soluções procedimentais aponta no sentido de buscar a complementação do atual modelo de democracia representativa (SANTOS, 2007, p. 91-93).

Em outra mão, Robert Dahl (1988, 100-102) ainda aponta, de maneira mais objetiva, algumas razões peculiares que poderiam explicar a tendência a não participação popular no processo político. Primeiramente, o autor reconhece que a própria variação quanto aos "prêmios" advindos da participação afetam a intensidade com que ela ocorre ${ }^{3}$, e isso tem maior influência quando o retorno público das aspirações e vontades particulares não é bastante ou adequado. Enfim, partindo-se de uma análise relacional de custo-benefício, "em suma, para muitas pessoas os custos de oportunidade do envolvimento político são elevados demais para justificar sua participação na vida política" ${ }^{\prime 4}$. Em de-

3 Tais "prêmios", por exemplo, variam desde gratificações diretas, como o exercício da cidadania em si, o comportamento de inclusão social etc., até vantagens instrumentais, que podem ser particulares e afetar o ambiente do indivíduo (obtenção de emprego, autorização pública para fazer algo etc.) ou coletivas, que afetam grupos numerosos (contribuintes, segurados da previdência social, etc.) (DAHL, 1988, p. 99-100).

4 "Os indivíduos arcam com custos para adquirir informações sobre determinados assuntos, empregam recursos e tempo para investigar, coletar e estudar dados e tomar decisões aptas a influenciar o cenário estatal. Tal custo apenas é aceitável e justificável se os mesmos indivíduos forem capazes de constatar que o esforço empregado foi devidamente recompensado, ou seja, que foram diretamente beneficiados pelas ações e escolhas políticas que influenciaram" - equilíbrio que é mais facilmente alcançado na comunidade local (OLIVEIRA, 2010, p. 23), o que já evidencia a relação entre democracia e federalismo. 
corrência disso, Dahl elenca, em segundo lugar, o sentimento de indiferença política do cidadão como estímulo à sua abstenção: indiferença de sua participação diante das alternativas disponíveis e, consequentemente, indiferença de suas escolhas - e, no campo específico da democracia representativa, a sensação de indiferença quanto aos partidos políticos atuantes. Entrelaçado com o segundo, o terceiro motivo reconhecido pelo autor reside no sentimento popular de que a participação de cada cidadão praticamente não acarreta qualquer diferença ao processo político, porquanto não pode ele alterar significativamente a realidade da vida política ${ }^{5}$. Soma-se a isso, em decorrência, a sensação generalizada de que resultados políticos que acarretem benefícios, na percepção do cidadão, podem ser obtidos, sem que o indivíduo se envolva - "a confiança extrema na legitimidade, justiça, estabilidade e equidade das decisões tomadas dentro do sistema político podem fazer com que o indivíduo considere desnecessária sua participação". Ademais, identifica-se no grau de conhecimento, capacidade, instrução do cidadão uma condicionante para o seu envolvimento político, de modo que, quão menor for um, menor será outro. E isso se pauta, principalmente, no sentimento individual de que a ação singular terá sempre uma eficácia limitada. E, por fim, o autor percebe que a inclinação para a participação política será sempre inversamente proporcional à estruturação dos óbices à atuação popular - obstáculos que podem ser burocráticos, procedimentais e, certamente, socioeconômicos (DAHL, 1988, p. 100-102). E esta última constatação retoma a ideia sobre a necessidade de criação de meios e condições para a atuação efetiva dos cidadãos na esfera pública.

Nesse diapasão, Farlei Riccio de Oliveira (2011, p. 205), ao analisar o pensamento de Robert Dahl, resume em três as que seriam tidas por este autor como condições essenciais para o processo democrático, em que os cidadãos devem ter oportunidades plenas de (a) formular publicamente suas preferências, (b) expressá-las à sociedade e ao governo, e (c) tê-las consideradas, indiscriminadamente, na conduta estatal.

Trata-se, portanto, não apenas de criarem-se mecanismos para o acesso do indivíduo ao processo político, mas também para que essa participação cause, de fato, algum efeito prático na deliberação pública.

Inegavelmente, o processo democrático acompanha a evolução cultural de cada população (HERTEI, 2007, p. 30), mas deve sempre ser guiado pela ideia-chave de que - novamente - "democracia significa identidade entre governantes e governados, entre sujeito e objeto do poder, governo do povo sobre o povo" (KELSEN, 2000, p. 35).

Nesse contexto, a tendência tradicional, anteriormente apresentada pelo princípio democrático representativo, vem considerando a representação po-

5 Estas são as palavras de Robert Dahl (1988, p. 101): "seja seu julgamento realista ou não, muitos cidadãos acreditam que as autoridades não prestam atenção a 'gente como nós'”. 
lítica, por meio do exercício do direito de voto e do processo eleitoral, como a única manifestação de participação popular e a única forma de realização o princípio democrático; contudo, tal modalidade de participação já não se pode apresentar como suficiente para qualificar e consolidar os preceitos da democracia (HERTEL, 2007, p. 114-115).

Certamente, a ideia corrente de cidadania já não se limita à tradicional concepção de uma ligação formal entre indivíduo e Estado, mas passa a enfeixar "um conjunto de direitos e deveres relacionais à liberdade, à igualdade e à justiça, pressupondo exatamente a possibilidade de interferência, na geração de normas jurídicas, dos seus próprios destinatários" (MARTINS, 2007, p. 34).

Por isso se reconhece que o funcionamento do regime democrático deve ser, cada vez mais, direto, a partir da implantação de um efetivo Estado de bem-estar social, que fomente a difusão das virtudes públicas e da instituição de instrumentos de participação (AGRA, 2005, p. 77). Mas, para tanto, não se pode descartar que a formação histórica e o conjunto de tradições que se acumularam ao longo dos anos por um povo influem, diretamente, na construção democrática (HERTEL, 2007, p. 30).

Tradicionalmente, o acesso aos mecanismos de tomada de decisão e construção de mediação sempre foi, no Brasil assim como na maioria dos países em desenvolvimento, privilégio das elites, e, por isso, a criação de instrumentos que incluem cidadãos historicamente excluídos das decisões políticas e do controle da gestão pública apresenta-se como desafio permanente (OLIVEIRA, 2003, p. 72). Afinal, a participação popular constitui o elemento chave para a caracterização do processo democrático: somente por meio da participação de toda a sociedade nesse processo é que a democracia refletirá a vontade soberana do povo (HERTEL, 2007, p. 31), de modo a apontar, invariavelmente, para uma progressão participativa e emancipatória, que já avança com lentidão, mas em grau e qualidade consideráveis (BONAVIDES, 2008, p. 58).

E é nessa perspectiva que se consolida o núcleo axiológico do governo republicano, que se forma sobre as bases do princípio democrático, do autogoverno e da isonomia (AGRA, 2005, p. 13).

Nesse contexto, Juarez Freitas (2011, p. 12) resume, ainda, três razões que explicariam o sobressalto da preferência pela consolidação da participação democrática. Primeiramente, porque a democracia representativa não resta prejudicada nessa proposta, sequer enfraquecida, mas, ao contrário, tende a ser arejada e fortalecida pela participação ativa da cidadania ${ }^{6}$. Em segundo lugar, porque o sistema representativo, ao que tudo indica, sozinho não levará a termo uma séria reforma política, tarefa que demanda a pressão vigorosa do poder

6 Não se pode negar, pois, que a "sociedade de partidos" está em crise, acentuada pelo reconhecimento da legitimidade do pluralismo das sociedades contemporâneas, com seus múltiplos padrões axiológicos e identidades culturais (ALMEIDA FILHO, 2006, p. 43). 
participativo. E, além disso, porque todo poder político precisa ser reequacionado de maneira responsável e a responsabilidade mostra-se inversamente proporcional à delegação exacerbada de poderes.

Parece certo, então, que a tendência moderna dos preceitos da democracia e do desenvolvimento social aponta para a participação popular, "na combinação entre a democracia representativa e as várias expressões de democracia direta" (BENEVIDES, 2009, p. 726), tratando-se, pois, de uma busca pela legitimação das instituições sociais e jurídicas, no contexto de um constitucionalismo que efetivamente abrace a democracia, propiciando que os cidadãos participem e promovam mudanças no próprio sistema político em vigor (SOUZA, 2010, p. 445).

Ademais, os mecanismos para o exercício do poder democrático, além de apontarem, no Estado Democrático de Direito, na direção da necessidade de concretização do princípio participativo, caracterizado pelo envolvimento direto e pessoal do povo na formação dos atos de governo, permitem a necessária compreensão de outro fenômeno sociopolítico, que é o do pluralismo, o qual deve ser capaz de edificar o equilíbrio entre as variadas tensões, conciliar a sociabilidade e o individualismo e administrar os antagonismos existentes (ROBERT, 2006, p. 228).

Afinal, a compreensão da cidadania como direito de todos, nesse contexto, somente se efetiva na medida em que todo cidadão tem suas singularidades respeitadas, como sujeito que vive em uma determinada cultura social e colabora no processo de sua transformação e consolidação (SOUZA, 2010, p. 453). Certamente, é a ideia de pluralismo, vivificado no respeito à diversidade, que permite a consolidação de valores característicos dos ideais democráticos, como a solução pacífica dos conflitos sociais, a eliminação da violência institucional (no limite do factível), o frequente revezamento da classe política, a tolerância - e assim por diante (BOBBIO et al, 2007, p. 326).

Como se pode perceber, então, é indiscutível que os novos paradigmas do Estado constitucional sinalizam na imbricação entre pluralismo e participação. Uma democracia que, mais do que participativa, deve ser inclusiva. E não é à toa que Paulo Bonavides (2010, p. 571) classifica como direitos fundamentais "de quarta geração" o direito à democracia, o direito à informação e o direito ao pluralismo, pois "deles depende a concretização da sociedade aberta do futuro, em sua dimensão de máxima universalidade, para a qual parece o mundo inclinar-se no plano de todas as relações de convivência".

É diante dessa perspectiva sociopolítica e com base em suas implicações jurídicas que se fixa o objeto do presente trabalho. Uma análise da relação que se pode identificar entre constitucionalismo, democracia e federalismo, certamente, não deve ser confinada aos conceitos tradicionais que envolvem a matéria ou aos elementos formais que indicam sua engessada compreensão; mas 
há de firmar-se a partir dos novos paradigmas do Estado Democrático, que se sustentam no plano do pluralismo e da participação.

\section{CIDADANIA DEMOCRÁTICA: PLURALISMO E PARTICIPAÇÃO}

Além dos inconvenientes mencionados como decorrência do funcionalismo pendular da democracia, que se interpola entre a "vontade da maioria" e a ideia de "igualdade entre cidadãos", a manutenção do regime representativo praticamente anula a possibilidade de uma isonomia substancial, que subsiste apenas na ótica formal, desvirtuando, implicitamente, a noção de governo do povo, pelo povo e para o povo, em que se assenta a base do Estado Democrático (CUNHA JÚNIOR, 2011, p. 526). Mas, além dessa temida "ditadura da maioria", um dos maiores perigos que pode vivenciar um regime democrático seria o que Stuart Mill (1981, p. 68) chamou de "interesses sinistros dos detentores do poder":

[...] é o perigo da legislação de classe; do governo que visa (com sucesso ou não) o benefício imediato da classe dominante, em perpétuo detrimento da massa. $\mathrm{E}$ uma das questões que mais merece consideração, quando se pretende determinar a melhor constituição de um governo representativo, é como reunir precauções contra esse mal.

Como solução, certamente, aponta-se a institucionalização de mecanismos para a inclusão, justamente, da massa popular nos processos decisórios, com a implementação de uma democracia participativa, que, por conseguir, implicitamente, ampliar a agenda política (SANTOS, 2007, p. 95), deve - longe de excluir - funcionar como uma espécie de reforço ou complemento ao sistema representativo (BOBBIO, 1986, p. 52).

É certo que a democracia direta - tal qual dos antigos regimes gregos - é impraticável nas sociedades contemporâneas, mas, de outro lado, é inegável que a perduração da democracia formal dos regimes liberal-representativos já acarretou a desvirtuação dos princípios basilares da democracia, a qual se deveria traduzir, inexoravelmente, como processo de participação dos governados na formação da vontade governativa (BONAVIDES, 2008, p. 57). E, conforme se percebe, esse postulado não vem conseguindo ser contemplado pelo sistema tradicional de representação - o que torna imprescindível, portanto, uma reformulação. Afinal, se a democracia direta não pode se sobrepor à representativa, esta também não pode, simplesmente, prevalecer sobre aquela (FONESCA, 2003, p. 295). É justamente por isso que se faz presente a aspiração ou tendência à democracia semidireta (pelos menos), mas que permita a distribuição do poder decisório entre os cidadãos, o que possibilita o reforço do controle social e, consequentemente, otimiza a efetivação dos direitos fundamentais (OLIVEIRA, 2011, p. 210). 
Na participação popular, aliás, mantém-se a horizontalidade das relações que estabelecem os contatos entre as coletividades sociais, característica que permite o desempenho de uma cultura democrática para o processo político (OLIVEIRA, 2003, p. 64). Afinal, são os atores sociais, por meio das suas ações cotidianas, que determinam a edificação do conceito democrático, e não a mera consciência individual dos agentes públicos (HERTEL, 2007, p. 32).

Assim, conforme alerta Farlei Riccio de Oliveira (2011, p. 203-204), nas sociedades contemporâneas, os direitos de participação do cidadão devem ser assegurados no sistema de direitos fundamentais, e instrumentalizados permanentemente pelo Estado ${ }^{7}$, de modo a evitar seu isolamento do espaço público de deliberação e a formação de um contexto antidemocrático. Nesse diapasão, a democracia vai sendo construída juntamente com a formação social, pois o povo deve constituir, ao mesmo tempo, sujeito e objeto do processo político democrático constitucional (HERTEL, 2007, p. 31).

Certamente, de todas as funções políticas dos regimes democráticos, a mais importante ainda é a normativa (WALDRON, 2001, p. 230) e, por isso, a modalidade de participação não se pode resumir à mera atuação nas eleições, de forma indireta, por meio de representação política; envolve, sobretudo, a participação direta do povo nas decisões estatais (HERTEL, 2007, p. 121). Afinal, como atenta Paulo Bonavides (2008, p. 245), "por um certo prisma, governar é legislar; governo é legislatio; governa quem legisla. Em se tratando, porém, de democracia, há que atender a este requisito fundamental: legisla quem tem legitimidade. E legitimidade quem a tem é o povo".

$\mathrm{E}$, nesse sentido, o fator que deve motivar a população a participar do processo governativo é que seu futuro será decidido a partir das decisões tomadas nos órgãos políticos; "o autogoverno acalentado sustenta-se na participação ativa dos cidadãos nas decisões políticas, em um processo legislativo que conte com a atuação e a legitimação da ampla maioria da população" (AGRA, 2005, p. 76). Ademais, o self-government atende à finalidade primordial do republicanismo, que é "garantir a liberdade" (AGRA, 2005, p. 75), traduzindo o axioma de que "politicamente livre é quem está sujeito a uma ordem jurídica de cuja criação participa" (KELSEN, 1992, p. 278). A participação dos cidadãos, porém, deve superar os mecanismos de simplória atuação esporádica e limitada factividade, de modo que a sociedade atue com efetividade na deliberação política:

Os cidadãos, ao formularem as atividades estatais, se sentem corresponsáveis pelas opções adotadas e vinculados ao destino escolhido. O espaço público torna-

7 Não obstante as limitações burocrático-procedimentais à viabilidade dos institutos até agora implementados na maioria dos sistemas políticos (referendo, plebiscito etc.), a democracia participativa deve ser continuamente estimulada, por meio da criação de novos veículos e espaços de participação, que permitam o pronunciamento dos cidadãos sobre as leis que Ihe são aplicadas, bem como o enfrentamento direto das questões políticas por parte da população (AUBERT, 2001, p. 207-208). 
-se locus em que reafirmam suas prerrogativas em igualdades de condições e compartilham do mesmo sentimento de aderência social.

[...]

O autogoverno dos cidadãos como essência da organização política se configura na única alternativa à privatização dos espaços públicos e da própria República. Mostra-se ainda como antídoto contra a despolitização da vida social, fazendo com que as escolhas efetivadas sejam tomadas no espaço público, retornando os cidadãos ao papel de protagonista do regime democrático de governo. (AGRA, 2005, p. 79-80)

E a tendência que se segue, nesse contexto, aponta para uma ordem política que deve ser vista como um processo deliberativo, cujo núcleo estruturante deve resguardar a atuação da sociedade em um espaço comum e horizontal de conjugação de diversas opiniões e aspirações, pois um sistema democrático deve permitir que os cidadãos sejam titulares de um amplo leque de direitos políticos, liberdades e oportunidades - de participar, de investigar as opções viáveis, de expressar ideias etc. (DAHL, 2001, p. 62).

Mas, da mesma forma em que para Alfred Stepan (1999, p. 4) a consolidação democrática é beneficiada quando se dedica atenção a três valores nucleares do sistema político - liberdade, igualdade e eficácia -, de modo que nenhum deles seja negligenciado e todos se reforcem mutuamente, Cláudio Souza Neto (2010, p. 11-12) lembra que o sentimento republicano de pertença à comunidade política, responsável por incitar nos indivíduos a vontade de participar do processo democrático, somente terá vazão, se estiver sedimentado o respeito mútuo pelas distinções socioeconômicas de cada cidadão, sem o qual este não se autocompreenderá como integrante da comunidade nem se envolverá na deliberação pública, enfraquecendo a cidadania constitucional. É indispensável, portanto, que haja condições de participação não apenas procedimentais, mas substanciais:

Sem o processo de aprimoramento das condições de socialização, e de constituição de espaços de intersubjetividades, torna-se impossível pensar os rumos do processo de radicalização da democracia. E isto é uma questão política, sem dúvida, e igualmente, econômica. São os imperativos sistêmicos da economia mercantil que definem uma condição tal de socialização, que os indivíduos se mostram absolutamente encubados pela retificação dos laços sociais, fator que degenera a interação social, na medida em que danifica a própria razão em funcionamento. (BITTAR, 2011, p. 114)

É imprescindível, então, que a estruturação das formas de participação seja acompanhada de um processo socioeconômico evolutivo. E, nessa encosta, observa-se que a efetivação das políticas públicas tende a ser mais eficaz, quando "discutidas e formadas a partir de um amplo processo de engajamento dos atores sociais, numa relação dialética entre Estado e sociedade que permita 
a consolidação de uma cidadania governante" (HERMANY, 2012, p. 89). Nessa perspectiva, o sistema democrático que emerge tende a ser aquele pautado na intercomunicação, em que dialogam os cidadãos e os órgãos estatais, dando margem a uma democracia deliberativa, cuja consolidação assenta nos pilares do multiculturalismo e da informação. E aqui ganha destaque a teoria do discurso, fomentada por Jürgen Habermas, da qual não se poderá desvincular esse paradigma democrático que desponta:

A teoria do discurso conta com a intersubjetividade de processos de entendimentos, situada num nível superior, os quais se realizam através de procedimentos democráticos ou na rede comunicacional de esferas públicas políticas. Essas comunicações destituídas de sujeito - que acontecem dentro e fora do complexo parlamentar e de suas corporações - formam arenas nas quais pode acontecer uma formação mais ou menos racional da opinião e a vontade acerca de matérias relevantes para toda a sociedade e necessitadas de regulamentação. O fluxo comunicacional que serpeia entre formação pública da conta, decisões institucionalizadas e deliberações legislativas, garante a transformação do poder produzido comunicativamente, e da influência adquirida através da publicidade, em poder aplicável administrativamente pelo caminho da legislação. Como no modelo liberal, as fronteiras entre "estado" e "sociedade" são respeitadas; porém, aqui, a sociedade civil, tomada como base social de esferas públicas autônomas, distingue-se tanto do sistema econômico, como da administração pública. Dessa compreensão da democracia resulta a exigência normativa de um deslocamento de pesos nas relações entre dinheiro, poder administrativo e solidariedade, a partir das quais as sociedades modernas satisfazem suas necessidades de integração e de regulação. Aqui as implicações normativas são evidentes: a força social e integradora da solidariedade, que não pode ser extraída apenas de fontes do agir comunicativo, deve desenvolver-se através de um amplo leque de esferas públicas autônomas e de processos de formação democrática da opinião e da vontade, institucionalizados através de uma constituição, e atingir os outros mecanismos da integração social - o dinheiro e o poder administrativo - através do medium do direito. (HABERMAS, 1997, p. 21-22)

O modelo de democracia que desponta, assim, é aquele que, a partir de uma abertura do debate político, entra em substituição dos corpos formalmente representativos, "cuja pravidade e degenerescência os aliena da vontade popular, até então pedestal de uma legitimidade perdida" (BONAVIDES, 2008, p. 344-345).

Frank Cunningham aponta, nesse contexto, os elementos que essencialmente devem ser considerados para a configuração de um sistema de democracia deliberativa. Primeiramente, ocupa-se o autor da primazia da legitimação, no sentido de que, para que a deliberação confira legitimidade ao procedimento democrático e a seus resultados, razões e ideais devem ser publicamente oferecidos e trocados em foros adequados para esse propósito, além de os participantes deverem ser aptos para, livre e igualitariamente, chegarem a pre- 
ferências informadas e a adquirirem e exercitarem as habilidades requeridas para a participação efetiva. Aduz o autor, ainda, que a deliberação democrática somente terá sentido e lugar em uma sociedade quando houver desentendimento entre os cidadãos acerca da fixação e execução das políticas públicas e, em consequência disso, o autor reconhece a capacidade e o pressuposto de agregação que acompanha o sistema deliberativo, que deve significar mais do que o simples ato de votar e, certamente, não se pode limitar apenas como meio de registro de preferências. Afinal, "a deliberação democrática sincera encoraja os cidadãos a procurarem consenso sobre os bens comuns" (CUNNINGHAM, 2009, p. 195-197).

Sistematicamente, então, a teoria discursiva de Habermas encontraria suporte fático-jurídico de aplicação, principalmente, nos espaços públicos locais, em que pode ocorrer a participação efetiva da sociedade civil, que poderá dialogar, racionalmente, na busca de consenso, fortalecendo o exercício da cidadania (SANTIN, 2010, p. 429-430).

E é nessa conjuntura que, afirma Boaventura de Sousa Santos (2007, p. 95), "uma democracia participativa no nível local consegue articular autorização com prestação de contas $^{8}$, cria realmente uma transparência, limita a corrupção - de fato isso está demonstrado - e consegue redistribuição social".

E é justamente no espaço social em que se encontra o povo, que tem atuação mais dinâmica na esfera pública local, que a democracia deliberativa pode subsistir de maneira rentável, pois é na pólis que há maior chance para uma igualdade de "possibilidades" de participação; é onde se pratica a solidariedade entre os comuns e onde as regras do convívio adaptam-se à sociedade pluralista contemporânea ${ }^{9}$, gerando uma cultura de cidadania, pertencimento e dignidade (HERMANY, 2012, p. 96-97).

Nesse contexto, então, é inegável que tanto a descentralização quanto a pluralização dos espaços de deliberação mostram-se técnicas de extensão da cidadania, fomentando uma ativa fiscalização social, permitindo, ademais, que todos participem do processo decisório em igualdade de condições (ZIMMERMANN, 2005, p. 165), o que acaba sendo pré-requisito para a consolidação da democracia deliberativa, que demanda que todos os cidadãos possam, efetivamente, influenciar as decisões públicas, sob pena de criar-se uma situação de exclusão sociopolítica (SOUZA NETO, 2010, p. 17-18).

8 Para Boaventura de Souza Santos (2007, p. 91-92), autorização e prestação de contas seriam as duas "pernas" (ou as duas vias) da democracia representativa. E a razão de crise desse sistema formal, conforme o autor, é que, atualmente, mantemos a prática de autorização, pelo voto, sem que se vislumbre, contudo, a prestação de contas (controle social). Por isso haveria a necessidade de avançar no terreno da democracia participativa.

9 A democracia deliberativa, por um lado, supõe uma interação comunicativa e, por outro, sugere uma autocompreensão dos participantes como sujeitos dignos de respeito e consideração, gerando um sentimento de identificação e pertencimento à comunidade política e integração social num contexto de pluralismo (SOUZA NETO, 2011, p. 8-9). 
Como se pode perceber, então, essa democracia participativo-inclusiva, baseada na Teoria do Discurso habermasiana, mostra-se como tendência evolutiva e complementar da tradição liberal-representativa, que passa a ser orientada pelo princípio da participação popular (HERTEL, 2007, p. 111-112). Afinal, como assenta Walber de Moura Agra (2005, p. 79), "o dínamo do regime democrático consiste na intensa participação política dos cidadãos nos negócios da pólis"10.

De outro lado, para que seja alcançado e instituído um novo modelo de participação democrática, faz-se imprescindível, em sede teórica, repolitizar a legitimidade e, no campo positivo e objetivo, repolitizar também a legalidade (BONAVIDES, 2008, p. 346). E isso perpassa, inevitavelmente, o campo do pluralismo.

Primeiramente, porque o ideal de igualdade política entre os cidadãos, âmago da democracia, implica, ao mesmo tempo, o reconhecimento da diversidade sociocultural dos indivíduos, ou seja, o reconhecimento das minorias (em contrapeso à "ditadura da maioria"), como prática de inclusão sociopolítica, em uma inversão à homogeneização cultural, que é praticamente inexistente na contemporaneidade (SOUZA NETO, 2010, p. 18). Aliás, a dialética maioria-minoria, tida tradicionalmente como ponto central da decisão democrática, fora concebida e adaptada pelas sociedades ainda do começo do século XX, que se mostravam como contraposições de tipo bipolar; "hoje isso parece algo demasiadamente rígido para sociedades complexas" (SANTORO, 2011, p. 83).

Além disso, a participação democrática que aqui se toma como referência trabalha com critérios de iguais oportunidades e equânime apreciação de propostas e aspirações, principalmente em uma sociedade multicultural, de modo a permitir uma deliberação comunicativa em que se somam diferentes projetos que visam ao bem comum, o que fomenta o desenvolvimento do sentimento de inclusão e pertencimento. Mas, no âmbito do pluralismo político, o significado de "povo soberano" desprende-se da conotação postulada pelas

10 Reforçando a plausibilidade dos sistemas participativos, Juarez Freitas refuta o que considera as cinco principais críticas comumente opostas à proposta de democracia direta, em oposição ao sistema representativo. Primeiramente, sobre o risco de desordem ou entropia do processo operacional, verifica-se que, já no modelo tradicional representativo, há propensão ao fracasso das regras, em virtude também da discricionariedade ilimitada que titulariza os eleitos, até por não responderem diretamente diante de seus eleitores. Em segundo lugar, diz o autor, não se teria como impraticável e enfadonho o processo democrático direto, porquanto não se deveria levar à deliberação popular toda e qualquer especulação política, de modo a esvaziar o regime representativo; deve-se buscar a aproximação entre os dois tipos de exercício. A terceira crítica rebatida por Freitas baseia-se nos supostos erros das decisões coletivas sobre matérias técnicas, o que, todavia, não impediria que os cidadãos operassem diretamente, na verdade, as macrodecisões. Além disso, a respeito do risco de descontrole responsivo das deliberações populares, o autor já reconhece nas instâncias representativas uma grande incidência de considerações desvinculadas de finalidades propícias; propõe-se, então, que o cidadão possa participar desse debate. Por fim, em resposta aos que apostam no despreparo do povo como razão para não se dar azo à democracia direta, Juarez Freitas retruca que - além de esse ser argumento de mesmo teor daquilo que retardou, sem justificativa, a abolição da escravatura - é necessário promover-se um grande processo de reeducação decisória e conscientização cidadã, para que se permita dar aos indivíduos a liberdade de gerir seu próprio destino político (FREITAS, 2011, p. 21-22). 
teorias liberal-representativas do século XX, superando a ideia de comunidade de história e de destino, passando de uma sociedade relativamente homogênea, no plano cultural, para uma sociedade plural; é, sobretudo e em primeiro lugar, "a soma dos particularismos, das diversidades culturais, das comunidades, das etnias, das religiões" (SANTORO, 2011, p. 78).

Ora, se democracia significa uma construção cultural, decorrente dos fatores sociais, políticos, jurídicos, econômicos e axiológicos que imperam em uma determinada sociedade (HERTEL, 2007, p. 29), então, quão maior for a diversidade no âmbito desses fatores, maior diversidade o processo democrático deve contemplar, de modo que a dimensão normativa do pluralismo, enquanto expressão e organização da esfera pública, deve corresponder à dimensão política do princípio democrático, elemento constitutivo da ordem constitucional (CANOTILHO, 2011, p. 1.411). E, nesse caminhar, os elementos de um sistema pluralista, segundo Wolkmer e Fagundes (2011, p. 374), poderiam assim ser identificados em valores como autonomia, descentralização, participação, localismo, diversidade e tolerância.

Vê-se, então, que o pluralismo implica, desde logo, a redistribuição dos centros de poder (BOBBIO, 1994, p. 32) e, retoricamente, "O alargamento de espaços de ação e de decisão políticas faz jus ao pluralismo ínsito às sociedades atuais que demanda acessibilidade à visibilidade pública, ao debate e à decisão" (PEREIRA, 2010, p. 175). Além disso, na esteira da descrição anterior, percebe-se que "a construção de uma sociedade democrática pode ser alicerçada na percepção valorativa das necessidades locais, dependentes não só da participação social, mas da existência de cidadãos conscientes dos seus direitos políticos e dos deveres do Estado" (ZIMMERMANN, 2005, p. 165). E daí sobressai, ainda, a ideia de oposição política como função decorrente do pluralismo, da qual deriva o direito de discordar, fiscalizar e buscar a alternância governativa, condições ínsitas à democracia e imprescindíveis à cidadania (F. MORAES, 2010, p. 150).

Assim, imbricam-se no espaço público tanto a possibilidade de atuação dos diferentes grupos sociais (pluralismo) quanto a abertura do processo político para os cidadãos (isonomia), de modo que, no atual Estado constitucional, deve imperar a noção de contrafluxo e equilíbrio entre unidade e pluralidade (BOBBIO, 1994, p. 32).

O pluralismo traduz, certamente, os anseios das sociedades atuais, cujos processos políticos tendem a superar a (ultrapassada) busca pela homogeneização social, que se alastrou a partir de conceitos como o nacionalismo e a democracia formal:

Democracia liberal e Estado nacional são inseparáveis: a regra da decisão democrática se funda sobre o pressuposto de que sobre muitas questões exista um acordo "pré-político" que garanta que a solução de tais questões não demandará jamais uma decisão "democrática". 
[...] a disciplina e o mito da nação, e do Estado nacional como expressão da identidade nacional, foram os instrumentos pelos quais foi construída a unidade "pré-política". (SANTORO, 2011, p. 71-73)

Como se nota, a concretização dos valores históricos e intrínsecos da democracia requer, inevitavelmente, a revisitação e a releitura de tradicionais paradigmas institucionais do constitucionalismo e da política, o que parte, necessariamente, de uma distribuição dos meios de participação no processo político, possibilitando-se ao maior número de cidadãos o envolvimento com as mais variadas e complexas questões que incidem as sociedades democráticas, em especial, aquelas para as quais se faz essencial a atuação das minorias que traduzem o pluralismo sociopolítico.

E essa ampliação da participação conta, certamente, com a multiplicação e abertura dos centros de decisão, acentuando-se o caráter democrático desse processo. Afinal, conforme anota Bobbio (1986, p. 28), o crescimento democrático em uma sociedade é identificado antes pelo aumento dos espaços políticos onde se pode dar a participação do que pelo número de sujeitos que tomam assento nas decisões.

Vê-se, portanto, que é da pluralização dos meios de decisão que decorre o aspecto democrático dos processos sociopolíticos. E é na imagem dessa sociedade desconcentrada - pluralizada, portanto - que se potencializa a ideia de democracia apoiada no conceito de discurso, contemplando-se nos espaços políticos de deliberação pública, especialmente no âmbito local, "uma arena para a percepção, a identificação e o tratamento de problemas de toda a sociedade" (HABERMAS, 1997, p. 24), tendo-se em vista que os anseios sociais, a conjuntura política, o cenário jurídico, os ditames econômicos, os valores presentes em uma sociedade são, sempre, fatores que determinam o desenvolvimento do processo democrático (HERTEL, 2007, p. 29-30).

Diante destes novos horizontes, então, pode-se perceber que o pluralismo é, de fato, não apenas característica, mas condição da democracia. E, dessa forma, não é possível desvincularem-se a ideia de participação social nas decisões públicas do ideal de pluralidade política, que, em uma perspectiva igualitária e inclusiva, deve orientar o desenvolvimento das sociedades democráticas contemporâneas.

Nesse sentido, Roberta Baggio (2006, p. 167) reconhece que, em um contexto em que a ordem institucional é comumente afetada pelos avanços da globalização econômica, em que se põem em cheque a estabilidade política e a identidade social da Constituição, somente a prática de uma cidadania que cultive valores como solidariedade e participação popular poderá subverter a homogeneização esterilizantemente disseminada, o que, invariavelmente, deve ter como palco o ambiente local, isto é, o espaço de "encontro das subjetividades". 


\section{FEDERALISMO E IDENTIDADE CONSTITUCIONAL}

Conforme retoma Norberto Bobbio (1994, p. 28), a configuração de um regime democrático implica, por definição, duas de suas finalidades instrumentais: a negação do poder autocrático e a negação do poder monocrático. E é certo reconhecer, assim, que, na presença de um dos dois, a democracia estará ausente.

Como forma de negação de um poder autocrático, é fundamental que governantes e governados compartilhem a prerrogativa de confabular as decisões sobre a coisa pública, o que deve envolver, em uma nova perspectiva sociopolítica, a participação efetiva dos cidadãos, que deve ser substancial e inclusiva, não meramente retórica: participar do processo político, então, poderá significar impedir que as decisões sejam tomadas autocraticamente. Já para a segunda negação - do poder monocrático -, pode-se apontar como uma solução, indisfarçadamente, a distribuição dos centros de poder, que é característica de um sistema pluralista, ou seja, do pluralismo político: a concentração do espaço decisório, afinal, retira a legitimidade das decisões mais abrangentes.

Em suma, o respeito ao pluralismo e o estímulo à participação substancial do povo são condições inafastáveis para a efetivação de um regime democrático. E o que se pode verificar, nesse contexto, é que justamente o federalismo, a partir de seus pressupostos teóricos e consequências fáticas, enquanto teoria do Estado e doutrina sociopolítica, pode oferecer - ou, ao menos, potencializar condições instrumentais para melhor desenvolvimento dos princípios da democracia contemporânea, que se alastram nos ideais de pluralismo e participação. Na doutrina, de fato, é comum que se afirme haver uma estreita ligação entre esses termos. Para Leonardo Martins (2009, p. 692), o próprio federalismo, em si, já possuiria como valores inerentes o "pluralismo e a democracia".

Os elementos de caracterização de um sistema federativo podem variar - e variam, certamente - em cada Federação, não se podendo, por óbvio, querer condicionar a identificação do federalismo a uma regra-geral, até mesmo porque a imagem do Estado federal deve antes ser construída a partir de uma consolidação histórico-pragmática do que de uma base teórico-abstrata (SEGADO, 2003, p. 448).

Entretanto, pode-se reconhecer, com base na doutrina de Bernardes (2010, p. 66-67), que há uma característica que é fundamental para a existência do Estado federal, sem a qual não há federalismo: a divisão interna de poder, que acarreta a convivência de mais de um ordenamento jurídico-constitucional. Isso quer dizer, portanto, que a descentralização do poder político é a essência do federalismo (BARACHO, 1986, p. 43).

E é justamente nessa característica que se afirma a autonomia das unidades federadas e a existência de um campo de decisão política próprio das populações locais (BRAGA, 2012, p. 72-73), que passam a exercer seu autogover- 
no, inclusive configurando a composição dos poderes públicos (A. MORAES, 2010, p. 152). Nesse sentido, uma das principais vantagens que decorre de um processo de descentralização política é a possibilidade de participação social nos programas e atividades governamentais (ZIMMERMANN, 2005, p 152), de modo que o autogoverno das localidades deve ser uma realidade no processo federativo, do qual ainda decorre, ademais, a autonomia de auto-organização, na qual se observa que o poder político para tanto reconhecido às entidades locais implica em uma competência para exercer o chamado poder constituinte decorrente (SOUZA NETO, 2010, p. 106), destinado a "institucionalizar coletividades, com caráter de organizações políticas regionais" (CUNHA JÚNIOR, 2011, p. 255). Assim, mais do que competências administrativas e legislativas, as entidades que compõem a Federação possuem competência constitucional, para elaborar e promulgar normas fundamentais de funcionamento e organização do poder local (ROBERT; MAGALHÃES, 2002, p. 38). E isso permite o início da construção de uma identidade constitucional.

E, nessa linha, assim como no constitucionalismo ordinário, a função básica de uma Constituição local deve estar voltada para a criação, organização e, consequentemente, limitação do poder estatal (GARDNER, 2012, p. 29). Essa organização institucional, portanto, vem a ser insculpida nas Constituições "infranacionais", validadas por um poder constituinte que se assenta na autonomia política das unidades federadas. Assim, nas Federações, as ordens parciais de poder - centro e periferia - detêm espaços próprios de atuação, cada uma com matriz constitucional própria (BERNARDES, 2010, p. 69). Nesse sentido, então, o surgimento de Constituições locais vem sendo proporcional à própria proliferação do federalismo no mundo (GARDNER, 2012, p. 23), de modo que, assim como há vários arranjos federativos estruturais, também variam, consequentemente, as normas constantes das Constituições regionais, nas várias realidades.

Nesse contexto, ademais, se o constitucionalismo ordinariamente tem por eixo de gravitação os direitos fundamentais, é plausível que um constitucionalismo local ${ }^{11}$ permita que as entidades infranacionais utilizem sua autonomia política para reforçar a proteção dos direitos dos cidadãos, por meio, inclusive, de uma eficaz organização do governo em uma atuação harmônica, porém independente do poder central (GARDNER, 2012, p. 25, 32 e 42), de modo a permitir o desenvolvimento, por iniciativa dos governos locais, "de suas políticas e seus próprios programas"12 (RAMOS, 2010, p. 723).

11 Cumpre ressaltar, todavia, que nem sempre esse avanço institucional das entidades locais está atrelado à existência ou previsão de uma Constituição formal. Conforme relata James Gardner (2012, p. 28), as províncias do Canadá - com exceção da Columbia Britânica - são exemplos de autogovernos que se instituem por meio de um constitucionalismo não escrito. Percebe-se, portanto, que o federalismo não necessariamente dependerá de autorização formal para estar presente; a autonomia político-constitucional das localidades nem sempre estará consubstanciada na existência de uma Constituição escrita.

12 Nesse sentido, Wilba Bernardes (2010, p. 46) reconhece que a completude do federalismo, enquanto fenômeno sociopolítico-jurídico, somente se dá na própria incompletude da estruturação normativa e das orientações do Texto Constitucional central, isto é, quando é deixado espaço político suficiente para a formulação das adequações locais. 
No panorama democrático, essa autonomia para auto-organização local dá vazão - ao mesmo tempo em que se deve - à ideia de pluralismo, como um dos valores inerentes da Federação (MARTINS, 2009, p. 692), que se pode exprimir em diferentes circunstâncias, desde que a Constituição regional seja expressão das crenças e aspirações de cada população, revelando-se de modos claramente distintos e, em uma perspectiva de autodeterminação política, refletindo características diversas de acordo com cada realidade local (GARDNER, 2012, p. 32). Por isso, observar Zimmermann (2005, p. 157):

Conquanto os anseios e necessidades sejam variáveis de região para região, de povo para povo, de município para município, é salutar que uma estrutura federativa seja suficientemente flexível, para que possamos nos adaptar às exigências específicas de cada contextualidade.

E essa adequação às condições socioeconômicas de cada região, aliás, deve pautar a atuação dos próprios membros federativos, levando em conta os anseios de cada população. A estipulação e execução de políticas públicas, instrumentos de concretização da Constituição material ${ }^{13}$, tendem a ser mais eficazes quando "discutidas e formadas a partir de um amplo processo de engajamento dos atores sociais, numa relação dialética entre Estado e sociedade que permita a consolidação de uma cidadania governante" (HERMANY, 2012, p. 89). E isso também destaca a importância da autonomia governativa local para a identidade política em um constitucionalismo substancial ${ }^{14}$.

Nesse contexto, então, é certo que a pluralidade de centros de poder aloja-se como princípio fundamental do federalismo, um panorama da unidade na diversidade, "numa perspectiva que ultrapassa a simples análise da forma do Estado, mas que apreende as perspectivas histórica, social, cultural e econômica" (CORRALO, 2009, p. 141).

A sociedade civil de laços federativos deve ser aquela em que os cidadãos percebem-se integrantes de uma unidade global, mas, ao mesmo tempo, partícipes de uma realidade social particular, sendo que, no sentimento geral, as duas identidades coexistem, sem eliminarem-se, assumindo um caráter bipolar (BOBBIO; MATTEUCCI; PASQUINO, 2007, p. 482). E, assim, é justamente nes-

13 "[...] a Constituição real [material, em distinção da Constituição formal] é a organização normativa de poderes, públicos ou privados, efetivamente em vigor em determinada sociedade, organização essa composta de costumes, convenções e leis escritas, fundada na tradição e correspondente à mentalidade social predominante, isto é, aos valores, às opiniões e à visão de mundo, prevalecentes no meio social. [...] Ela corresponde, em tudo e por tudo, à noção de politéia da Grécia antiga, a qual Isócrates definia como a alma da pólis, isto é, sua personalidade própria." (COMPARATO, 2010, p. 238-239)

14 Se uma comunidade política constitucional é socialmente pluralista, ela, ao mesmo tempo, é implicitamente fragmentada, e isso subscreve o ímpeto natural de busca por uma identidade constitucional, que seja compartilhada por todos; e, nesse sentido, as visões subjetivas, no contexto interno da comunidade, nutrem-se da conciliação intersubjetiva, no enfoque de inclusão. E esse tratamento inclusivo pode exprimirse no reconhecimento e aceitação das diferenças, não apenas como tolerância, mas até como incentivo à diversidade, fomentando-se uma atmosfera de respeito mútuo e cooperação (ROSENFELD, 2003, p. 111-113). E aqui, novamente, os preceitos do federalismo ganham destaque, conforme anuncia o estudo. 
sa tensão que o federalismo mostra-se a opção viável para as atuais sociedades - fragmentadas e pluralistas ${ }^{15}$-, nas formas de organizações territoriais de poder (BERNARDES, 2010, p. 48).

Ora, quando ocorre a centralização política, o poder passa a ostentar um caráter nacional (homogêneo), e isso se contrapõe à opção pela multiplicação dos centros de decisão, inerente ao federalismo, o qual, justamente por isso, permite que o processo político seja realizado de maneira dinâmica e viva (heterogênea). Como decorrência, constata-se que um sistema constitucional em que o poder político manifesta-se sempre em nível nacional, ou seja, sem a base do autogoverno local, é uma democracia apenas nominal, "porque controla, do alto, sufocando as comunidades, isto é, a vida concreta dos homens" (BOBBIO; MATTEUCCI; PASQUINO, 2007, p. 482).

E daí advém a percepção de que há necessidade de superar a sistemática política de cunho centralista, não apenas para legitimar o exercício do poder, mas para torná-lo adequado. Essa visão, aliás, encontra perfeita ressonância nas observações de Hans Kelsen (1992, p. 305) sobre os postulados de concreção dos valores democráticos:

A democracia exige a conformidade máxima entre a vontade geral expressa na ordem jurídica e a vontade dos indivíduos sujeitos à ordem; por essa razão, a ordem jurídica é criada pelos próprios indivíduos por ela obrigados, de acordo com o princípio da maioria. A conformidade da ordem à vontade da maioria é o objetivo da organização democrática. Mas as normas centrais da ordem, válidas para o território inteiro, podem facilmente entrar em contradição com a vontade majoritária de um grupo que vive num território parcial. O fato de que a maioria da comunidade total pertença a certo partido político, nacionalidade, raça, língua ou religião; a maioria da nação inteira poder ser liberal ou protestante. Para diminuir a possível contradição entre o conteúdo da ordem jurídica e a vontade dos indivíduos a ela sujeitos, para que se chegue o mais próximo possível do ideal de democracia, pode ser necessário que, sob certas circunstâncias, certas normas da ordem jurídica sejam válidas apenas para certos territórios parciais e sejam criadas apenas pelo voto majoritário dos indivíduos que vivem nesses territórios. Com a condição de que a população do Estado não possua uma estrutura social uniforme, a divisão territorial do Estado em províncias mais ou menos autônomas [...] pode ser um postulado democrático.

O federalismo, assim, surge como potencial mecanismo para a promoção das adaptações normativas à diversidade social, de modo a tornar adequada e legítima a atividade constitucional. E a autonomia das unidades políticas

15 O pluralismo pode ser visto na vigência do Estado Democrático de Direito, tanto como uma circunstância fática, de projeção social, quanto como uma ideia normativa, cujo abrigo deve ser a ordem constitucional, marcada pela seguinte dicotomia: funcionar como critério jurídico para reconhecer a diversidade sociocultural, bem como para conciliá-la por meio das soluções apresentadas pelo ordenamento (ALMEIDA FILHO, 2006, p. 41). 
regionais, conceito base do Estado federal, revela-se mecanismo institucional de limitação ao centralismo nacional que permite, ao mesmo tempo, essa vinculação da ordem estatal ao particularismo local. Vê-se, então, que o federalismo acaba retomando os objetivos do constitucionalismo moderno, ao trabalhar as ideias de limitação ao poder político e de participação na construção desse poder, em uma tendência de resgate da legitimação democrática e da integração social (BERNARDES, 2010, p. 45). Afinal, ressalta Paulo Napoleão da Silva (2006, p. 91-95), a perenização do constitucionalismo depende sempre de sua adaptação social, não sendo função sua esterilizar ou uniformizar culturas e realidades sociais distintas.

E, nessa perspectiva, a descentralização do federalismo - princípio de justiça social pela distribuição de poder e controle recíproco - há de considerar, ao lado do princípio da separação orgânica das funções estatais, um agente de equilíbrio das forças políticas (ZIMMERMANN, 2005, p. 161); uma limitação recíproca entre o Governo Federal e cada governo local (GARDNER, 2012, p. 39-40).

Além disso, o contrapeso que a autonomia local impinge à tendência homogeneizante da "maioria" nacional permite que as populações viventes em distintas regiões recebam o tratamento jurídico-político mais adequado, principalmente se lhes é resguardado o direito de participar das formulações políticas que Ihes dizem respeito:

A esfera local potencializa a ideia de pertencimento, de responsabilidade social, estimulando, dada a proximidade do processo decisório, a ativa participação da sociedade, o que acarreta inúmeros benefícios. Portanto, o fator que se constata em todas as estratégias bem-sucedidas de poder local reside no maior grau de abertura dos processos decisórios para a população. (HERMANY, 2012, p. 95)

Por isso, afirma Martins (2009, p. 696) que, na estrutura do federalismo democrático, na qual se dividem as esferas de decisão, é necessário garantir que os indivíduos possam discutir livremente, no âmbito local, as suas identidades sociais, prioridades institucionais, entendimentos políticos e equacionamentos econômicos. $\mathrm{E}$, nesse sentido, é imprescindível que a autonomia política das unidades regionais possa torná-las suficientemente independentes de qualquer imposição ou neutralização institucional, conferindo-se à sociedade local a prerrogativa de ditar o seu próprio destino, na busca da consolidação de uma identidade constitucional. Afinal, "a perspectiva da democracia na federação [...] exige uma garantia da participação do indivíduo no processo político, para que todos os homens sejam considerados livres e iguais" (MARTINS, 2009, p. 697).

Nesse contexto, é evidente que ao grau de autonomia local para deliberar e legislar sobre importantes matérias, da maneira mais adequada a cada realidade socioeconômica, corresponderá, proporcionalmente, maior controle sobre 
práticas homogeneizantes, até mesmo porque os atores políticos que se encontram mais próximos da realidade viva dos cidadãos é que poderão melhor desenvolver as engrenagens estatais para atender ao interesse popular (REVERBEL, 2012, p. 38). Afinal, como reconhece Canotilho (2011, p. 702-703), "as mudanças estruturais da sociedade tornam clara a necessidade de o direito não ser considerado como regulador heterónomo de relações sociais, mas como instrumento de trabalho para auto-regulação" (grifos no original). Dessa forma, é impossível não se enxergar na autonomia política pertinente ao federalismo a resposta mais adequada para as demandas constitucionais da contemporaneidade.

A concretização da democracia requer a remoção dos bloqueios que retardam sua marcha, de modo que se desobstruam os caminhos da participação (BONAVIDES, 2008, p. 58), consolidando-se os espaços abertos em que possam ser expostas as ideias da comunidade, que poderá reivindicar as práticas políticas que atendam às suas prioridades (SANTIN, 2010, p. 422), e que a autonomia política local vira conceito-chave:

Entendemos que o federalismo deve ser compreendido a partir da noção de pluralismo defendida por Habermas, que se apresenta tanto como defesa das concepções individuais de vida digna, como defesa das várias formas de identidades sociais e coletiva. Também entendemos que o federalismo é concretizado quando da organização dessa nova sociedade e vai melhor permitir dar vazão à concepção de democracia procedimental da sua Teoria do Discurso. (BERNARDES, 2010, p. 17)

Ora, se a ideia de que a Constituição, enquanto marco nacional, identifica normativamente a vontade popular e já não se sustenta de maneira generalizada, são necessários instrumentos institucionais que estabeleçam essa correspondência, em um sistema que abrigue a linha de continuidade entre a normatividade constitucional e a realidade do povo, nas atuais sociedades complexas, nas quais devem conviver marcos axiológicos e critérios normativos distintos, no seio de um pluralismo social que depende do discurso normativo pluralista para garantir o "direito à diferença" e diminuir a conflituosidade, de modo que, como assenta Agassiz Almeida Filho, o futuro do constitucionalismo dependerá, assim, de dois aspectos essenciais: a legitimidade da Constituição, focada na correspondência entre sua expressão e a vontade popular, bem como na sua eficácia social. E, aqui, resta ainda mais acentuada a ideia de que a identidade constitucional deve ser formulada a partir da proximidade entre o ambiente de construção normativa e os sujeitos que nela se expressam ${ }^{16}$, de modo que se possam superar as falhas no processo de comunicação intersubjetiva, que têm comprometido as bases racionais do ordenamento e que dificultaram

16 Afinal, a elaboração e, principalmente, a interpretação constitucional introduzem elementos que exercem influência na composição da identidade constitucional (ROSENFELD, 2003, p. 46). 
a harmonização de valores e estruturação de marcos de convivência (ALMEIDA FILHO, 2006, p. 39-45).

Assim sendo, não soa ilógico nem ilegítimo aduzir que, se os alicerces das constituições democráticas contemporâneas residem na soberania do povo, na proclamação de liberdades e na separação de poderes (ARDANT, 2001, p 219), "a federação constitui, portanto, a realização mais alta dos princípios do constitucionalismo" (BOBBIO; MATTEUCCl; PASQUINO, 2007, p. 482).

\section{CONCLUSÃO}

Um dos maiores bloqueios que são impostos ao desenvolvimento da cidadania decorre da crise política em que se encontram as instituições democráticas, que têm sido desvirtuadas pela força de condicionantes socioeconômicas, que distorcem e interferem diretamente nos valores constitucionais, os quais deveriam orientar o sistema sociopolítico.

E, como resposta natural a essa questão, os postulados da democracia, na contemporaneidade, clamam por uma revisão dos conceitos tradicionais de que antes se ocupava a ciência política, de modo a indicar a necessidade de superação de antigos paradigmas, a partir das demandas da democracia participativa e do pluralismo político.

Tais tendências, por certo, demandam uma revisitação do espaço público, em que se deve promover aproximação do povo com o exercício do poder. E a democracia contemporânea, nesse sentido, passa a requerer uma participação popular substancial, que permita a deliberação social sobre as questões que afetam diretamente o povo, em um espaço político no qual a pluralidade de demandas e a diversidade cultural dos atores possam ser catalisadas por um processo racional e inclusivo, de onde possa resultar o maior número de benefícios e o maior grau de satisfação para todos os setores da população. E esse espaço público, como visto, é a esfera local, e que a política e cidadania ganham vida, e a partir de onde uma Constituição deve ser construída e concretizada.

Tomando-se, por fim, tudo que foi estudado, pode-se afirmar que, no contexto da nova ordem global e do comprometimento dos projetos constitucionais nacionais, o federalismo sobressai como forma de aproximação entre sociedade e Estado, por fornecer a autonomia política ao espaço local, que acresce à sua natureza de ambiente de convívio, solidariedade e cidadania, o estrato de centro gravitacional de um constitucionalismo vivo, construído e concretizado em um processo dialógico, fortalecido pelo ponderamento social da participação popular, que resgata a legitimidade do espaço público, o que, por viabilizar a construção democrática de uma nova identidade constitucional, fornece bases para sua estabilidade institucional, legitimação política e eficácia social. 


\section{REFERÊNCIAS}

AGRA, Walber de Moura. Republicanismo. Porto Alegre: Livraria do Advogado, 2005.

ALMEIDA FILHO, Agassiz. Constituição e estado constitucional: ruptura ou continuidade dos paradigmas liberais? In: ALMEIDA FILHO, Agassiz; PINTO FILHO, Francisco Bilac Moreira (Coord.). Constitucionalismo e Estado. Rio de Janeiro: Forense, 2006.

ARDANT, Philippe. Os regimes constitucionais. In: DARTON, Robert; DUHAMEL, Olivier (Org.). Democracia. Trad. Clóvis Marques. Rio de Janeiro: Record, 2001.

ARISTÓTELES. Política. Trad. Pedro Constantin Tolens. 5. ed. São Paulo: Martin Claret, 2010.

AUBERT, Jean-François. Democracia direta. In: DARTON, Robert; DUHAMEL, Olivier (Org.). Democracia. Trad. Clóvis Marques. Rio de Janeiro: Record, 2001.

BAGGIO, Roberta Camineiro. Federalismo no contexto da nova ordem global. Curitiba: Juruá, 2006.

BAQUERO, Marcello. A desconfiança como fator de instabilidade política na América Latina. In: ; CASTRO, Henrique Carlos de Oliveira de; GONZÁLEZ, Rodrigo Stumpf (Org.). A construção da democracia na América Latina: estabilidade democrática, processos eleitorais, cidadania e cultura política. Porto Alegre: UFRGS, 1998.

BENEVIDES, Maria Victoria de Mesquita. Em defesa da república e da democracia. In:___ ; BERCOVICI, Gilberto; MELO, Claudineu de (Org.). Direitos humanos, democracia e república: Homenagem a Fábio Konder Comparato. São Paulo: Quartier Latin, 2009.

BERNARDES, Wilba Lúcia Maia. Federação e federalismo: uma análise com base na superação do estado nacional e no contexto do estado democrático de direito. Belo Horizonte: Del Rey, 2010.

BITTAR, Eduardo. Democracia, narcisismo social e individualismo: ensaio sobre Mímesis a partir de Axel Honneth. In: FREITAS, Juarez; TEIXEIRA, Anderson V. (Org.). Direito à democracia: ensaios interdisciplinares. São Paulo: Modelo, 2011.

BOBBIO, Norberto. As ideologias e o poder em crise: pluralismo, democracia, socialismo, comunismo, terceira via e terceira força. Trad. João Ferreira. 3. ed. Brasília: Universidade de Brasília, 1994.

. Liberalismo e democracia. Trad. Marco Aurélio Nogueira. São Paulo: Brasiliense, 2000.

- O futuro da democracia: uma defesa das regras do jogo. Trad. Marco Aurélio Nogueira. 6. ed. Rio de Janeiro: Paz e Terra, 1997.

; BOVERO, Michelangelo. Sociedade e estado na filosofia política moderna.

Trad. Carlos Nelson Coutinho. São Paulo: Brasiliense, 1986. 
; MATTEUCCI, Nicola; PASQUINO, Gianfranco. Dicionário de política. Trad. Carmen C. Varriale et al. 13. ed. Brasília: Universidade de Brasília, 2007. BONAVIDES, Paulo. Ciência política. 18. ed. São Paulo, Malheiros, 2011. Curso de direito constitucional. 25. ed. atual. São Paulo: Malheiros, 2010.

. Teoria constitucional da democracia participativa: por um direito constitucional de luta e resistência; por uma nova hermenêutica; por uma repolitização da legitimidade. 3. ed. São Paulo: Malheiros, 2008.

CANOTILHO, José Joaquim Gomes. Direito constitucional e teoria da constituição. 7. ed. Coimbra: Almedina, 2011.

COMPARATO, Fábio Konder. Rumo à justiça. São Paulo: Saraiva, 2010.

CUNHA JÚNIOR, Dirley da. Curso de direito constitucional. 5. ed. rev. ampl. e atual. Salvador: JusPodivm, 2011.

CUNNINGHAM, Frank. Teorias da democracia. Trad. Delmar José Volpato Dutra. Porto Alegre: Artmed, 2009.

DAHL, Robert. Análise política moderna. Trad. Sérgio Bath. 2. ed. Brasília: Universidade de Brasília, 1988. lia, 2001.

Sobre a democracia. Trad. Beatriz Sidou. Brasília: Universidade de Brasí-

FREITAS, Juarez. Direito constitucional à democracia. In: ; TEIXEIRA, Anderson V. (Org.). Direito à democracia: ensaios interdisciplinares. São Paulo: Modelo, 2011.

GOYARD-FABRE, Simone. O que é democracia? A genealogia filosófica de uma grande aventura humana. Trad. Claudia Berliner. São Paulo: Martins Fontes, 2003.

HABERMAS, Jürgen. Direito e democracia: entre facticidade e validade. Trad. Flávio Beno Siebeneichler. Rio de Janeiro: Tempo Brasileiro, 1997.

HERMANY, Ricardo. (Re)discutindo as políticas públicas no espaço local: interconexões entre federalismo, subsidiariedade e direito social no Brasil. In: MAUÉS, Antonio Moreira (Org.). Federalismo e constituição: estudos comparados. Rio de Janeiro: Lumen Juris, 2012.

HERTEL, Jaqueline Coutinho Saiter. As dimensões democráticas nas constituições brasileiras. Porto Alegre: Sergio Antonio Fabris, 2007.

KELSEN, Hans. A democracia. Trad. Ivone Castilho Benedetti, Jefferson Luiz Camargo, Marcelo Brandão Cipolla, Vera Barkow. 2. ed. São Paulo: Martins Fontes, 2000.

. Teoria geral do direito e do estado. Trad. Luís Carlos Borges. 2. ed. São Paulo: Martins Fontes, 1992

MARTINS, Fernando Barbalho. Do direito à democracia: neoconstitucionalismo, princípio democrático e crise no sistema representativo. Rio de Janeiro: Lumen Juris, 2007. 
MILL, John Stuart. Considerações sobre o governo representativo. Trad. Manoel Innocêncio de L. Santos Júnior. Brasília: Universidade de Brasília, 1981.

MORAES, Filomeno. Contrapontos: democracia, república e constituição no Brasil. Fortaleza: UFC, 2010.

MOSS, Robert. O colapso da democracia. Trad. Wilma Freitas Ronald de Carvalho. Brasília: Nórdica, 1977.

MÜLLER, Friedrich. A democracia em face da exclusão social. In: BAQUERO, Marcello; CASTRO, Henrique Carlos de Oliveira de; GONZÁLEZ, Rodrigo Stumpf (Org.). A construção da democracia na América Latina: estabilidade democrática, processos eleitorais, cidadania e cultura política. Porto Alegre: UFRGS, 1998.

NEVES, Marcelo. Entre Têmis e Leviatã: uma relação difícil - o Estado democrático de direito a partir e além de Luhmann e Habermas. 2. ed. São Paulo: Martins Fontes, 2008.

OLIVEIRA, Farlei Martins Riccio de. Esfera pública e participação na função administrativa do Estado: as contribuições de Hannah Arendt e Robert Dahl. In: FREITAS, Juarez; TEIXEIRA, Anderson V. (Org.). Direito à democracia: ensaios interdisciplinares. São Paulo: Modelo, 2011.

OLIVEIRA, Francisco Mesquita de. Cidadania e cultura política no poder local. Fortaleza: Fundação Konrad Adenauer, 2003.

PEREIRA, Rodolfo Viana. Direito constitucional democrático: controle e participação como elementos fundantes e garantidores da constitucionalidade. 2. ed. Rio de Janeiro: Lumen Juris, 2010.

REVERBEL, Carlos Eduardo Dieder. O federalismo numa visão tridimensional do direito. Porto Alegre: Livraria do Advogado, 2012.

ROBERT, Cinthia. Democracia e constituição: contribuições para a compreensão do Estado contemporâneo. Campinas: Millennium, 2006.

ROSENFELD, Michel. A identidade do sujeito constitucional. Trad. Menelick de Carvalho Netto. Belo Horizonte: Mandamentos, 2003.

SANTIN, Janaína Rigo. Poder local e gestão democrática municipal: uma análise a partir da teoria do discurso de Jürgen Habermas. In: HERMANY, Ricardo (Org.). Empoderamento social local. Santa Cruz do Sul: IPR, 2010.

SANTORO, Emilio. A democracia é ainda adaptável às sociedades multiculturais? In: FREITAS, Juarez; TEIXEIRA, Anderson V. (Org.). Direito à democracia: ensaios interdisciplinares. São Paulo: Modelo, 2011.

SANTOS, Boaventura de Sousa. Renovar a teoria crítica e reinventar a emancipação social. Trad. Mouzar Benedito. São Paulo: Boitempo, 2007.

SEGADO, Francisco Fernández. El federalismo en América Latina. Revista Latino-Americana de Estudos Constitucionais, Del Rey, n. 1, p. 447-476, jan./jun. 2003. 
SILVA, José Afonso da. Curso de direito constitucional positivo. 33. ed. rev. e atual. São Paulo: Malheiros, 2010.

SILVA, Paulo Napoleão Nogueira da. Atualidade do constitucionalismo. In: ALMEIDA FILHO, Agassiz; PINTO FILHO, Francisco Bilac Moreira (Coord.). Constitucionalismo e Estado. Rio de Janeiro: Forense, 2006.

SOUZA, Inês Cabral Ururahy de. Cidadania e direitos humanos no estado social e no constitucionalismo democrático. Pensar, Fortaleza, v. 15, n. 2, p. 442-456, jul./dez. 2010.

SOUZA NETO, Cláudio Pereira de. Constitucionalismo democrático e governo das razões: estudos de direito constitucional contemporâneo. Rio de Janeiro: Lumen Juris, 2010.

STEPAN, Alfred. Para uma nova análise comparativa do federalismo e da democracia: federações que restringem ou ampliam o poder do Demos. Dados, Rio de Janeiro, v. 42, n. 2, 1999. Disponível em: <http://www.scielo.br/scielo. php?script=sci_arttext\&pid=S0011-52581999000200001\&lng=en\&nrm=iso > . Acesso em: 11 nov. 2012.

WALDRON, Jeremy. A legislação. In: DARTON, Robert; DUHAMEL, Olivier (Org.). Democracia. Trad. Clóvis Marques. Rio de Janeiro: Record, 2001.

WOLKMER, Antônio Carlos; FAGUNDES, Lucas Machado. Tendências contemporâneas do constitucionalismo latino-americano: estado plurinacional e pluralismo jurídico. Pensar, Fortaleza, v. 16, n. 2, p. 371-408, jul./dez. 2011.

ZIMMERMANN, Augusto. Teoria geral do federalismo democrático. 2. ed. Rio de Janeiro: Lumen Juris, 2005. 